\title{
PENGARUH PRAPERLAKUAN ALKALI DAN ASAM TERHADAP KARAKTERISTIK MUTU BAKTO AGAR DARI RUMPUT LAUT Gelidiumsp.
}

\section{The Effect of Alkali and Acid Pretreatment to the Quality of Bacto Agar from Gelidium sp.}

\author{
Muhamad Darmawan $^{1 *}$, Joko santoso ${ }^{2}$, Dina Fransiska1, dan Marsella ${ }^{2}$ \\ ${ }^{1}$ Balai Besar Riset Pengolahan Produk dan Bioteknologi Kelautan dan Perikanan, \\ JI. KS Tubun, Petamburan VI, Slipi, Jakarta Pusat \\ ${ }^{2}$ Departemen Teknologi Hasil Perairan, Fakultas Perikanan dan IImu Kelautan, Institut Pertanian Bogor, \\ Jl. Darmaga, Bogor, Jawa Barat \\ *Korespondensi Penulis: m.darmawan22@gmail.com
}

Diterima: 31 Desember 2019; Direvisi: 27 Januari 2020; Disetujui: 31 Maret 2020

\begin{abstract}
ABSTRAK
Ekstraksi bakto agar dari rumput laut merah Gelidium sp. asal Pameungpeuk, Jawa Barat dengan praperlakuan alkali dan asam telah diteliti. Pada praperlakuan alkali digunakan $\mathrm{NaOH}$ dengan variasi konsentrasi 4,5 , dan $6 \%$. Asam yang digunakan yaitu $\mathrm{CH}_{3} \mathrm{COOH}$ dengan variasi konsentrasi $0,5 \%$ dan 1,0\%. Parameter mutu yang diamati meliputi kadar air, kadar abu, kadar abu tak larut asam, kadar sulfat, gugus fungsi, rendemen agar, kekuatan gel, viskositas, titik leleh dan titik jendal, sineresis, dan angka lempeng total. Bakto agar terbaik diperoleh dari praperlakuan dengan konsentrasi $\mathrm{NaOH}$ $4 \%$ dan $\mathrm{CH}_{3} \mathrm{COOH} 0,5 \%$ yang telah memenuhi beberapa persyaratan mutu bakto agar komersial untuk parameter kekuatan gel, kadar air, kadar abu, dan kadar abu tak larut asam. Karakteristik mutu

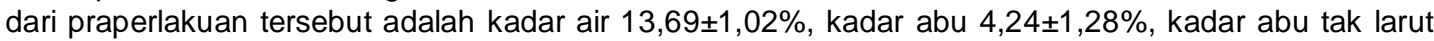
asam $0,54 \pm 0,25 \%$, kadar sulfat $1,55 \pm 0,36 \%$, rendemen $9,19 \pm 2,21 \%$, kekuatan gel 1464,98 $\pm 109,09$ $\mathrm{g} / \mathrm{cm}^{2}$, viskositas $42,75 \pm 24,40 \%$, sineresis $2,76 \pm 0,12 \%$, titik jendal $20,50 \pm 2,12{ }^{\circ} \mathrm{C}$, dan titik leleh $95,25 \pm 1,06$ ${ }^{\circ} \mathrm{C}$. Praperlakuan dengan konsentrasi tersebut juga memiliki nilai Angka Lempeng Total (ALT) yang sama dengan bakto agar komersial.
\end{abstract}

\section{KATA KUNCI : bakto agar, Gelidium sp., praperlakuan alkali dan asam}

\begin{abstract}
Bacto agar extraction from red seaweed Gelidium sp. from Pameungpeuk, West Java with alkali and acid pretreatment had been conducted. $\mathrm{NaOH}$ with concentration of 4,5 , and $6 \%$ was used for alkali pretreatment while $\mathrm{CH}_{3} \mathrm{COOH}$ at concentrations of $0.5 \%$ and $1.0 \%(\mathrm{v} / \mathrm{v})$ was used for acid pretreatment. The quality parameters investigated were moisture content, ash content, acid insoluble ash, sulphate content, functional groups, yield, gel strength, viscosity, melting point, gelling point, syneresis, and total plate count. The best quality of bacto agar was obtained by using $4 \%$ alkali pretreatment and $0.5 \% \mathrm{CH}_{3} \mathrm{COOH}$. This pretreatment has fulfilled the specification of commercial bacto agar for moisture, ash, acid inslouble ash content, and gel strength parameter. The properties of bacto agar from this pretreatment were moisture content $13.69 \pm 1.02 \%$, ash content $4.24 \pm 1.28 \%$, acid insoluble ash content $0.54 \pm 0.25 \%$, sulphate content $1.55 \pm 0.36 \%$, yield $9.19 \pm 2.21 \%$, gel strength $1464.98 \pm 109.09 \mathrm{~g} / \mathrm{cm}^{2}$, syneresis $2.76 \pm 0.12 \%$, gelling point $20.50 \pm 2.12{ }^{\circ} \mathrm{C}$, and melting point $95.25 \pm 1.06$ ${ }^{\circ} \mathrm{C}$. This pretreatment also gave the same result as the commercial bacto agar for the total plate count.
\end{abstract}

KEYWORDS: bacto agar, Gelidium sp., alkaline and acid pretreatment

\section{PENDAHULUAN}

Rumput laut merah Gelidium sp. bernilai ekonomis karena memiliki kemampuan untuk menghasilkan agar (Abidin, Marcellino, \& Sudjarwo, 2015). Agar terdapat di dalam matriks dan dinding sel rumput laut merah yang berasal dari famili Gelidiaceace dan
Glacilariaceae (Niu, Xu, Wang, Zhang, \& Peng, 2013). Agar dapat dimanfaatkan sebagai media untuk mengembangbiakkan bakteri dan mikroba lainnya seperti kapang dan khamir. Agar juga merupakan standar media untuk penelitian mikrobiologi lebih dari seabad (Santika, Widodo, \& Romadhon, 2014). Agar digunakan sebagai media pertumbuhan mikroba 
karena memiliki kemampuan membentuk gel pada suhu $30-40{ }^{\circ} \mathrm{C}$ dan mampu mencair pada suhu $65-85^{\circ} \mathrm{C}$ (Armisen \& Galatas, 2009; Humm \& Williams, 1948; Yarnpakdee Soottawat, \& Passakorn, 2015). Kemampuan ini membuat agar lebih stabil untuk media pertumbuhan mikrobiologi jika dibandingkan dengan gelatin yang memiliki titik leleh yang rendah yaitu $25-30^{\circ} \mathrm{C}$ (Armisen \& Galatas, 2009). Produksi rumput laut merah yang menghasilkan agar di Indonesia cukup tinggi, namun Indonesia masih tergantung sepenuhnya pada impor untuk memenuhi kebutuhan bakto agar di dalam negeri (Murdinah, Fransiska, \& Subaryono, 2008).

Gelidium sp. merupakan jenis rumput laut penghasil agar, rumput laut ini berpotensi untuk dikembangkan sebagai bahan baku pembuatan bakto agar. Pemanfaatan rumput laut Gelidium sp. di Indonesia masih sangat sedikit, sejauh ini rumput laut Gelidium sp. dieskpor dalam bentuk rumput laut kering. Industri pengolahan agar dari Gelidium sp. di dalam negeri masih kalah jika dibandingkan dengan industri pengolahan agar dari rumput laut Gracilaria sp. (Murdinah et al., 2008), walaupun kekuatan gel agar yang dihasilkan dari Gelidium sp. lebih tinggi (Sousa, Alves, Morais, Matos, \& Goncalves, 2010). Salah satu faktor penyebabnya adalah metode ekstraksi Gelidium sp. yang lebih sulit (Murdinah et al., 2008). Hal ini membuat perlu adanya metode ekstraksi agar yang sesuai untuk mendapatkan bakto agar dari Gelidium sp. Metode paling umum yang dilakukan untuk ekstraksi agar yaitu memanaskan rumput laut dalam air panas, menyaring, membekukan, dan melelehkan agar untuk menghilangkan air (Arvizu-Higuera et al., 2008).

Agar yang diekstrak dari Gelidium rigidium dengan menggunakan air selama 2 jam dalam autoklaf menghasilkan agar dengan kadar air 10,95\%, kadar abu tak larut asam $0,18 \%$, kadar sulfat 3,6\%, dan kekuatan gel $670,72 \mathrm{~g} / \mathrm{cm}^{2}$ (Murdinah et al., 2008). Penelitian Subaryono \& Murdinah (2011) menghasilkan agar dari Gracilaria chilensis dengan praperlakuan asam dengan rendemen $20,21 \%$, kadar sulfat $1,77 \%$, dan kekuatan gel $119,28 \mathrm{~g} / \mathrm{cm}^{2}$. Metode ekstraksi agar dengan praperlakuan asam memberikan nilai yang rendah pada kekuatan gel (Ramalingam, Kaliaperumal, \& Kalimuthu, 2002). Beberapa spesies membutuhkan praperlakuan alkali untuk meningkatkan kekuatan gel dan memperbaiki kualitas agar (Al-Nahdi, Al-Alawi, Al-Marhobi, \& AlZefiti, 2015). Praperlakuan alkali dengan $\mathrm{NaOH}$ menurut Santika et al. (2014) dapat meningkatkan kekuatan gel namun memiliki kelemahan yaitu rendahnya rendemen (Orduña-Rojas, et al., 2008) sehingga dibutuhkan perlakuan asam untuk meningkatkan rendemen (Distantina, Anggraeni, \&
Fitri, 2008). Ekstraksi agar dengan praperlakuan $\mathrm{NaOH}$ dapat mereduksi kandungan sulfat dengan menghidrolisis I-galaktosa-6-sulfat untuk menghasilkan 3,6-anhidrogalaktosa sehingga kekuatan gel yang diperoleh semakin tinggi (OrduñaRojas et al., 2008). Kombinasi praperlakuan asam dan alkali menurut Ganesan dan Rao (2004) dapat meningkatkan rendemen agar dengan titik jendal dan titik leleh yang tinggi.

Hasil penelitian Distantina, Rusman, dan Hartati (2006) menunjukkan rendemen agar yang diekstrak menggunakan $\mathrm{CH}_{3} \mathrm{COOH}$ lebih tinggi dibandingkan dengan $\mathrm{HCl}$. Perlakuan asam menggunakan $\mathrm{CH}_{3} \mathrm{COOH}$ lebih baik daripada penggunaan larutan $\mathrm{HCl}$ karena nilai rendemen agar yang dihasilkan lebih tinggi walaupun menggunakan konsentrasi yang lebih rendah (Distantina et al., 2006). $\mathrm{CH}_{3} \mathrm{COOH}$ dalam proses ekstraksi agar berfungsi menarik agar ke luar dari dinding sel (Kusuma, Santosa, \& Pramesti, 2013). Berdasarkan informasi tersebut maka perlu dilakukan penelitian tentang pengaruh praperlakukan $\mathrm{NaOH}$ dan $\mathrm{CH}_{3} \mathrm{COOH}$ terhadap mutu bakto agar dari Gelidium sp. Tujuan dari penelitian ini adalah untuk mempelajari pengaruh praperlakuan $\mathrm{NaOH}$ dan $\mathrm{CH}_{3} \mathrm{COOH}$ terhadap mutu bakto agar Gelidium sp. dengan konsentrasi berbeda dan membandingkannya dengan karakteristik mutu bakto agar komersial.

\section{BAHAN DAN METODE}

\section{Bahan}

Rumput laut Gelidium sp. berasal dari daerah Pameungpeuk, Jawa Barat. Bahan kimia berupa $\mathrm{NaOH}$ (Merck), $\mathrm{CH}_{3} \mathrm{COOH}$ (Merck), $\mathrm{NaOCl}$ (Merck), dan air digunakan dalam proses ekstraksi.

\section{Metode}

Pembuatan agar menggunakan metode yang dilakukan oleh Yarnpakdee et al. (2015) yang dimodifikasi. Gelidium sp. sebanyak $1 \mathrm{~kg}$ dicuci dan direndam dalam $10 \mathrm{~L}$ air selama 24 jam. Rumput laut dipanaskan dalam $10 \mathrm{~L}$ larutan $\mathrm{NaOH}$ dengan konsentrasi 4,5 , dan $6 \%$ pada suhu $85-90^{\circ} \mathrm{C}$ selama 1,5 jam lalu dicuci dengan air. Rumput laut direndam dalam larutan $\mathrm{CH}_{3} \mathrm{COOH} 10 \mathrm{~L}$ dengan konsentrasi $0,5 \%$ dan $1 \%$ selama 1 jam. Rumput laut kemudian dipucatkan dengan direndam dalam larutan $10 \mathrm{~L}$ $\mathrm{NaOCl} 4 \%$ selama 30 menit, kemudian dicuci hingga $\mathrm{pH}$ netral. Rumput laut diekstraksi selama 2 jam menggunakan air (1:10) pada suhu $80-90^{\circ} \mathrm{C}$, kemudian disaring dengan vibrator screen ukuran 100 mesh. Filtrat yang diperoleh dituang ke dalam pan dan dijendalkan selama 12-24 jam pada suhu kamar. Gel yang dihasilkan kemudian disimpan di cold 
storage selama 24 jam. Tahapan selanjutnya adalah pelelehan (thawing) gel agar dengan menggunakan air mengalir. Pengeringan agar dilakukan dengan bantuan sinar matahari. Proses selanjutnya adalah penepungan agar sehingga diperoleh bakto agar.

Kualitas mutu rumput laut yang digunakan dilihat dari parameter kadar clean anhydrous weed (CAW) (BSN, 2015a), impurities (BSN, 2015b), kadar air (BSN, 2015c). Bakto agar yang diperoleh dihitung rendemennya (Yousefi, Islami, \& Filizadeh, 2013), kemudian diamati kulitasnya, yang meliputi kadar air (BSN, 2015c), kadar abu (BSN, 2010), kadar abu tak larut asam (BSN, 2010), kadar sulfat (Heydari, Nematollahi, Motamedzadegan, Hosseini-Parvar, \& Hosseini, 2014), gugus fungsi (Czechowska-Biskup, Jarosiñska, Rokita, Ulañski, \& Rosiak, 2012), kekuatan gel (Yousefi et al., 2013), viskositas (Praiboon, Chirapart, Akakabe, Bhumibhamon, \& Kajiwara, 2006), titik leleh dan titik jendal (RodríguezMontesinos, Arvizu-Higuera, Hernández-Carmona, Muñoz-Ochoa, \& Murillo-Álvarez, 2013), sineresis (Villanueva, Sousa, Gonçalves, Nilsson, \& Hilliou, 2010), dan angka lempeng total (BSN, 2006a)

Rancangan percobaan pada penelitian ini adalah RAL faktorial dengan dua faktor yaitu $\mathrm{NaOH}$ dengan variasi konsentrasi 4,5 , dan $6 \%$ dan $\mathrm{CH}_{3} \mathrm{COOH}$ dengan konsentrasi 0,5 dan $1,0 \%$. Percobaan dilakukan masing-masing empat ulangan. Hasil pengamatan dianalisis dengan ANOVA menggunakan SPSS 21 dengan taraf signifikansi beda nyata ditentukan pada $p<0,05$. Uji lanjut yang digunakan dalam penelitian ini adalah uji wilayah berganda Duncan.

\section{HASIL DAN PEMBAHASAN}

Karakteristik mutu rumput laut Gelidium sp. yang digunakan dalam ekstraksi bakto agar meliputi kadar air, CAW, dan pengotor. Clean Anhydrous Weed (CAW) merupakan rumput laut kering yang telah bersih dari pengotor total seperti karang, rumput laut jenis lain, plastik, kerang, pasir, garam serta benda asing lainnya (BSN, 2015a). Pengotor adalah pengotor seperti rumput laut lain, pasir, garam dan kotoran lainnya yang menempel pada rumput laut (Utomo \& Satriyana 2006). Hasil karakteristik mutu rumput laut Gelidium sp. dapat dilihat pada Tabel 1.

Nilai kadar air Gelidium sp. lebih kecil dari standar SNI rumput laut kering yaitu sebesar $11,59 \%$ sehingga telah memenuhi standar SNI (BSN, 2015d). Kadar air rumput laut ini tidak jauh berbeda dengan nilai kadar air Gelidium pusillum yaitu sebesar 10,85\% (Siddique, Khan, \& Buiyan, 2013). Kadar air rumput laut memiliki keterkaitan dengan umur panen. Semakin tua umur panen rumput laut maka penyerapan air yang digunakan untuk proses sintesis polisakarida akan semakin banyak (Santika et al., 2014). Kadar CAW menunjukkan kebersihan rumput laut dari kotoran yang melekat seperti rumput laut lain, pasir dan karang (Utomo \& Satriyana, 2006). Hasil pengukuran diperoleh CAW Gelidium sp. sebesar 40,02\% dan telah memenuhi standar SNI. Dengan demikian, rumput laut Gelidium sp. memiliki kemurnian 40,02\%, sedangkan sisanya adalah air dan pengotor lainnya seperti pasir, garam dan bahan lainnya yang menempel.

Nilai pengotor Gelidium sp. yang digunakan pada pembuatan bakto agar melebihi nilai standar SNI yaitu sebesar $15,63 \%$. Pengotor pada rumput laut Gelidium sp. didominasi oleh pasir dan batu, tumbuhan lain, dan teritip. Tingginya nilai pengotor rumput laut disebabkan oleh penanganan rumput laut setelah dipanen. Rumput laut Gelidium sp. hasil pemanenan langsung dijemur di bawah sinar matahari tanpa melalui proses pencucian dengan menggunakan air tawar ataupun proses sortasi. Rumput laut kering dari jenis Gelidium memiliki kualitas yang rendah jika dibandingkan dengan Glacilaria sp. karena memiliki banyak pengotor dan banyaknya campuran dari rumput laut lain (Murdinah et al., 2008). Pengotor yang terdapat pada rumput laut dapat mempengaruhi kadar abu karena pengotor yang ada dapat ikut menjadi abu serta terukur sebagai kadar abu. Pengotor dapat dihilangkan dengan mengaduk rumput laut secara terus menerus pada proses pencucian dan mengulang pencucian hingga rumput laut bersih (Kumala, Sumarny, Racmani, \& Ruswita, 2013).

Tabel 1. Karakteristik mutu rumput laut Gelidium sp.

Table 1. Quality characteristics of Gelidium sp.

\begin{tabular}{lcc}
\hline Parameter/Parameters & Nilai/Value & $\begin{array}{c}\text { Syarat Mutu/Quality } \\
\text { requreiment (BSN, 2015d) }\end{array}$ \\
\hline Kadar air/Moisture content (\%) & $11.59 \pm 0.91$ & Maks.12/Max.12 \\
CAW/Clean anhydrous weed (\%) & $40.02 \pm 5.75$ & Min. 40/Min. 40 \\
Pengotor/Impurities (\%) & $15.63 \pm 2.48$ & Maks. 3/Max. 3 \\
\hline
\end{tabular}




\section{Karakteristik Bakto Agar}

\section{Kadar air}

Kadar air adalah jumlah air tidak terikat yang terdapat dalam suatu produk (BSN, 2006b). Nilai kadar air bakto agar berkisar antara 12,51-16,73\%. Analisis menunjukkan kadar air bakto agar dipengaruhi oleh praperlakuan $\mathrm{NaOH}$, praperlakuan $\mathrm{CH}_{3} \mathrm{COOH}$, dan interaksi keduanya $(p<0,05)$. Hasil analisis kadar air bakto agar dapat dilihat pada Gambar 1.

Kadar air bakto agar dengan praperlakuan $\mathrm{NaOH}$ $5 \%$ dan $\mathrm{CH}_{3} \mathrm{COOH} 1 \%$ tidak berbeda nyata dengan

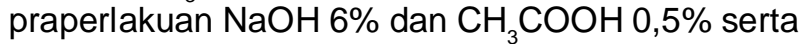
$1 \%$ namun berbeda nyata dengan praperlakuan lainnya. Kadar air bakto agar berkaitan dengan kadar sulfat. Muatan negatif ester sulfat dapat berikatan dengan air sehingga jika kadar sulfat tinggi maka kadar air juga tinggi (Wenno, Thenu, \& Lopulalan, 2012). Bakto agar dengan praperlakuan $\mathrm{NaOH} 4 \%$ dan $\mathrm{CH}_{3} \mathrm{COOH} 0,5$ dan $1 \%$, serta praperlakuan $\mathrm{NaOH}$ $5 \%$ dan $\mathrm{CH}_{3} \mathrm{COOH} 0,5 \%$ masuk ke dalam spesifikasi mutu bakto agar grade reguler. Praperlakuan $\mathrm{NaOH}$ $4 \%$ dan $\mathrm{CH}_{3} \mathrm{COOH} 0,5 \%$ merupakan praperlakuan terpilih karena menghasilkan kadar air yang memenuhi syarat mutu bakto agar dan tidak berbeda nyata terhadap praperlakuan lainnya. Perbaikan teknik dalam proses ekstraksi agar khususnya pada tahapan pengeringan mampu mengurangi kadar air agar . Kadar air agar yang lebih kecil mampu diperoleh melalui proses ekstraksi agar dengan menggunakan oven pada tahapan pengeringan (Darmawan, Syamdidi, \& Hastarini, 2006).

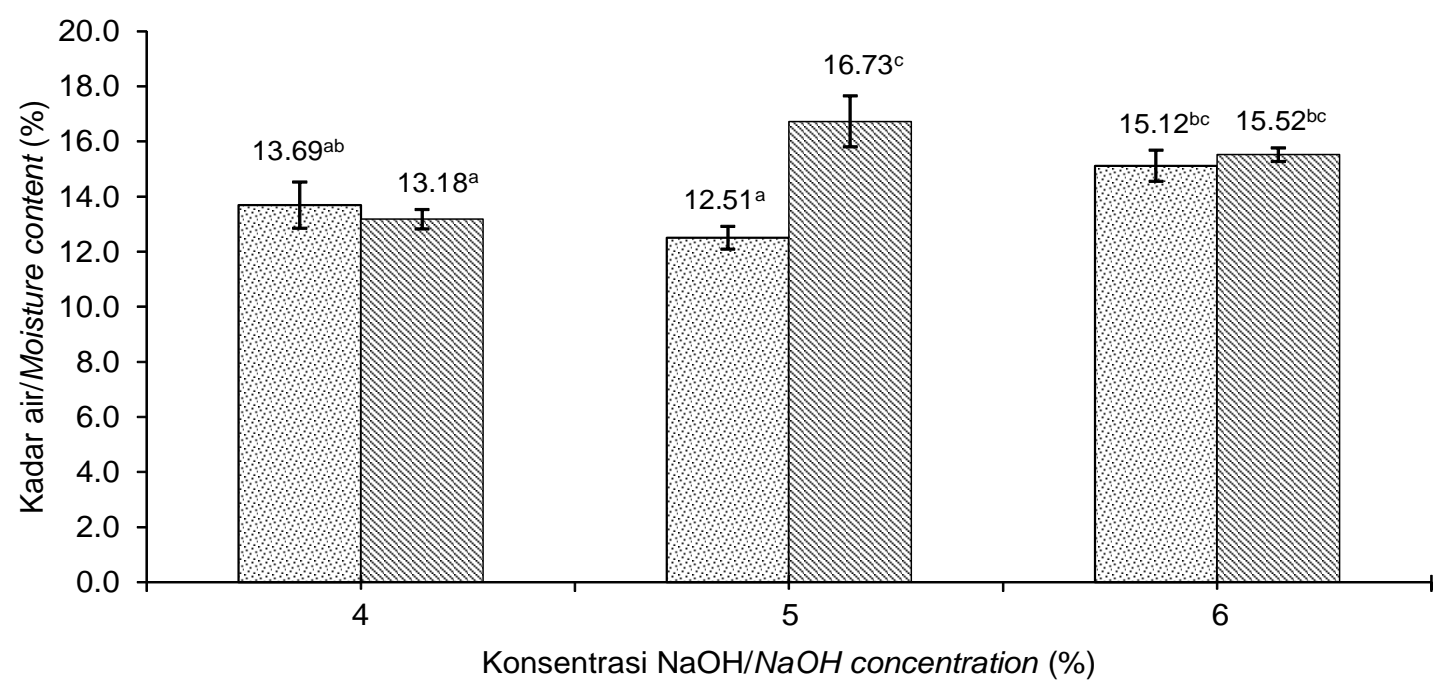

O $\mathrm{CH}_{3} \mathrm{COOH} 0,5 \% / 0.5 \% \mathrm{CH}_{3} \mathrm{COOH} \otimes \mathrm{CH}_{3} \mathrm{COOH} 1 \% / 1 \% \mathrm{CH}_{3} \mathrm{COOH}$

Keterangan/Note: Huruf yang sama menunjukkan tidak berbeda nyata/The same letters indicate no significant difference.

Gambar 1. Kadar air bakto agar

Figure 1. Moisture content of bacto agar

Tabel 2. Spesifikasi bakto agar komersial Supreme Marine Chemical

Table 2. Specification of commercial bacto agar Supreme Marine Chemical

\begin{tabular}{lccc}
\hline \multicolumn{1}{c}{ Parameter/Parameters } & Reguler/Reguler & Standar/Standard & Premium/Premium \\
\hline Kadar air/Moisture content $(\%)$ & $<15.0$ & $<12.0$ & $<9.0$ \\
Kadar abu/Ash content $(\%)$ & $<4.5$ & $<4.0$ & $<1.0$ \\
Kadar abu tak larut asam/ & $<1.0$ & $<1.0$ & $<1.0$ \\
Acid Insoluble ash content $(\%)$ & $400.0-500.0$ & $500.0-650.0$ & $>650.0$ \\
Kekuatan gel/Gel strength $\left(\mathrm{g} / \mathrm{cm}^{2}\right)$ & &
\end{tabular}

Sumber/Source: Anon. (2004) 


\section{Kadar abu}

Jumlah kandungan residu anorganik yang diperoleh dari proses pengabuan suatu produk disebut juga sebagai kadar abu (BSN, 2006c). Hasil analisis kadar abu bakto agar ditampilkan pada Gambar 2. Kadar abu bakto agar berkisar antara 4,22-6,92\%, di mana praperlakuan $\mathrm{NaOH}$ dan $\mathrm{CH}_{3} \mathrm{COOH}$ serta interaksi keduanya berpengaruh $(p<0,05)$ terhadap kadar abu bakto agar yang dihasilkan. Kadar abu bakto agar dengan praperlakuan $\mathrm{NaOH} 6 \%$ dan $\mathrm{CH}_{3} \mathrm{COOH} 0,5 \%$ tidak berbeda nyata terhadap praperlakuan $\mathrm{NaOH} 5 \%$ dan $\mathrm{CH}_{3} \mathrm{COOH} 0,5 \%$, serta praperlakuan $\mathrm{NaOH} 6 \%$ dan $\mathrm{CH}_{3} \mathrm{COOH} 1 \%$, namun berbeda nyata terhadap praperlakuan lainnya. Dengan konsentrasi $\mathrm{NaOH}$ yang sama, konsentrasi $\mathrm{CH}_{3} \mathrm{COOH}$ tidak berpengaruh terhadap kadar abu bakto agar.

Untuk nilai kadar abu bakto agar, terjadi peningkatan nilai kadar abu seiring dengan peningkatan konsentrasi alkali dan asam yang digunakan. Hasil penelitian Kusuma et al. (2013) juga menunjukkan bahwa terjadi kenaikan kadar abu agar seiring dengan meningkatnya konsentrasi $\mathrm{NaOH}$. Konsentrasi $\mathrm{NaOH}$ secara tidak langsung berperan dalam penentuan kadar abu. Kekuatan gel semakin tinggi dengan semakin tingginya konsentrasi $\mathrm{NaOH}$ yang digunakan (Santika et al., 2013), tingginya kekuatan gel akan membuat elemen mineral yang tersisa terperangkap dalam agar dan sulit untuk keluar (Kusuma et al., 2013).
Hasil analisis proksimat bakto agar yang dilakukan Efendi, Retno, dan Nursalam (2015) menghasilkan kadar abu agar Gelidium sebesar 2,17\%. Spesifikasi mutu bakto agar komersial berdasarkan nilai kadar abunya adalah sebesar kurang dari 4,5\% untuk grade regular, kurang dari $4 \%$ untuk grade standard, dan kurang dari $1 \%$ untuk grade premium (Anon. 2004). Kadar abu bakto agar yang diperoleh dengan

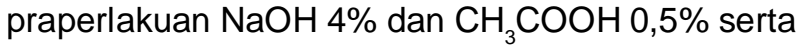
$1 \%$ memenuhi standar mutu kadar abu bakto agar komersial. Bakto agar dengan konsentrasi $\mathrm{NaOH} 4 \%$ dan $\mathrm{CH}_{3} \mathrm{COOH} 0,5 \%$ menjadi perlakuan terpilih karena merupakan konsentrasi terendah dan masuk kedalam spesifikasi mutu bakto agar komersial grade regular. Kadar abu dipengaruhi oleh proses pencucian rumput laut yang masih menyisakan karang dan pasir (Salamah, Susanti, \& Wikanta, 2005). Pengotor yang masih tersisa saat pencucian dapat terukur sebagai kadar abu dari agar (Kumala et al., 2013).

\section{Kadar abu tak larut asam}

Hasil analisis kadar abu tak larut asam bakto agar ditampilkan pada Gambar 3, di mana nilainya berkisar antara $0,51-0,93 \%$. Kadar abu tak larut asam bakto agar tidak dipengaruhi oleh praperlakuan $\mathrm{NaOH}$, praperlakuan $\mathrm{CH}_{3} \mathrm{COOH}$, dan interaksi keduanya $(p>0,05)$.

Kadar abu tak larut asam bakto agar untuk grade premium di bawah 1\% (Anon., 2004). Hal ini

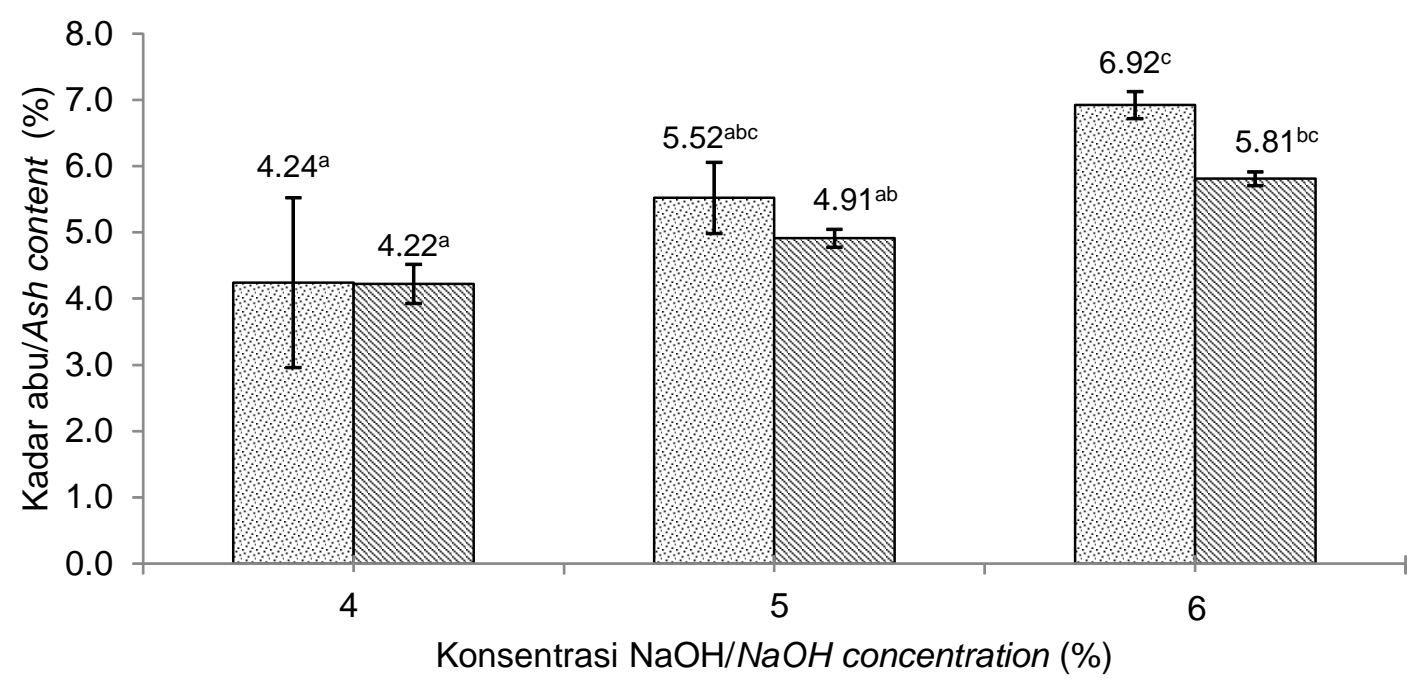

圆 $\mathrm{CH}_{3} \mathrm{COOH} 0,5 \% / 0.5 \% \mathrm{CH}_{3} \mathrm{COOH} \mathrm{CH}_{3} \mathrm{COOH} 1 \% / 1 \% \mathrm{CH}_{3} \mathrm{COOH}$

Keterangan/Note: Huruf yang sama menunjukkan tidak berbeda nyata/The same letters indicate no significant difference.

Gambar 2. Kadar abu bakto agar

Figure 2. Ash content of bacto agar 


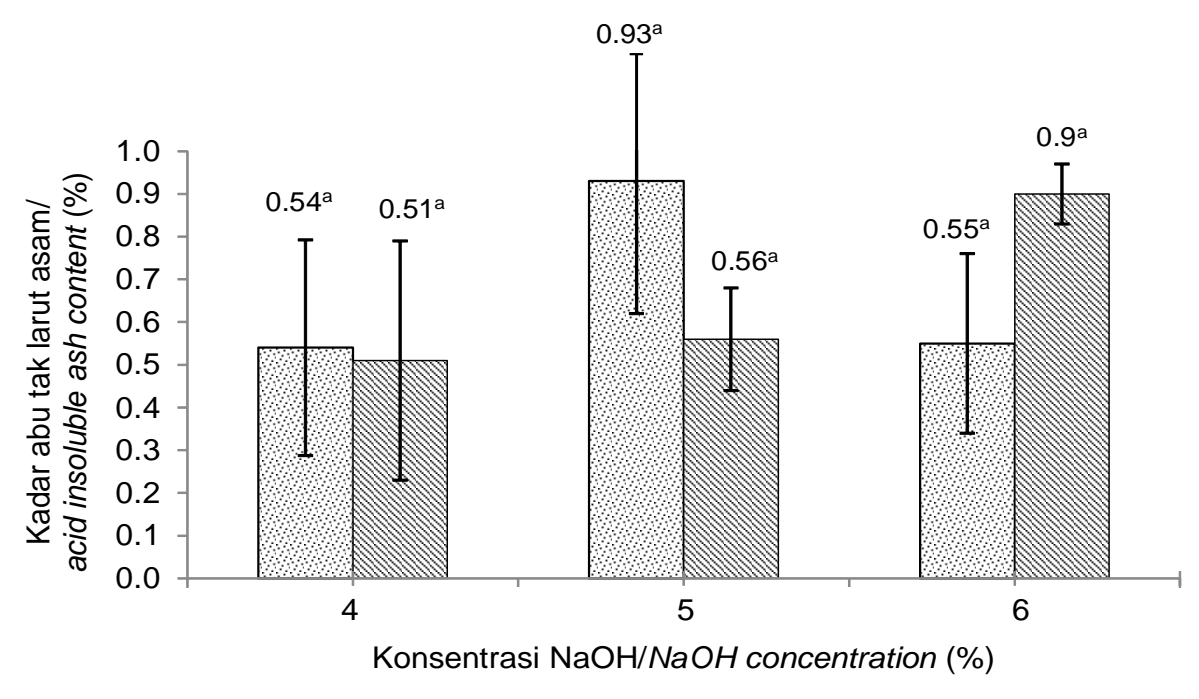

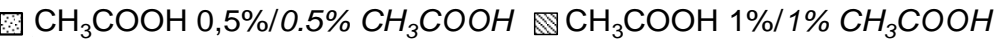

Keterangan/Note: Huruf yang sama menunjukkan tidak berbeda nyata/The same letters indicate no significant difference.

Gambar 3. Kadar abu tak larut asam bakto agar.

Figure 3. Acid insoluble ash content of bacto agar

menunjukkan bahwa bakto agar yang dihasilkan pada peneltian ini masuk ke dalam spesifikasi grade premium. Kadar abu tak larut asam pada bakto agar hasil penelitian Murdinah et al. (2008) sebesar 0,18$0,38 \%$. Kadar abu tak larut asam yang diekstrak dengan menggunakan air berkisar antara 0,38-0,76\%. Nilai kadar abu tak larut asam yang rendah menunjukkan bahwa kandungan logam berat pada bakto agar yang dihasilkan tersebut juga rendah (Kumala et al., 2013).

\section{Kadar sulfat}

Nilai rata-rata kadar sulfat bakto agar berkisar antara 1,54-2,61\%. Hasil analisis kadar sulfat bakto agar ditampilkan pada Gambar 4.

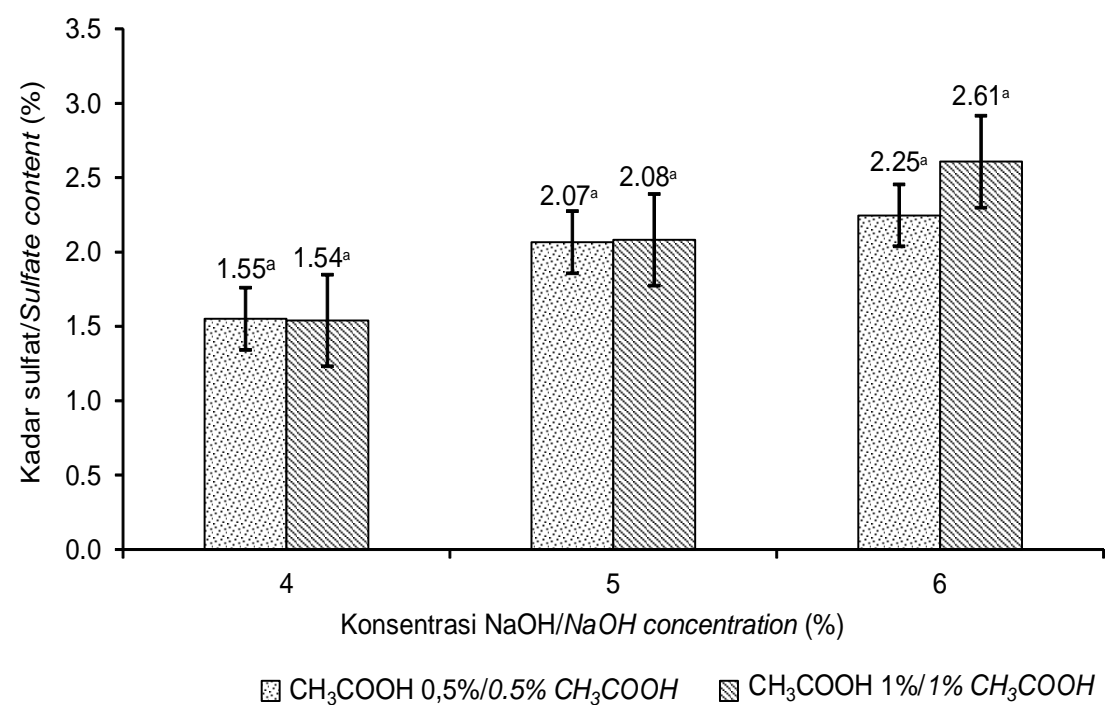

Keterangan/Note: Huruf yang sama menunjukkan tıdak berbeda nyata/ I he same letters Indicate no significant difference.

Gambar 4. Kadar sulfat bakto agar.

Figure 4. Sulfate content of bacto agar 
Pengaruh Praperlakuan Alkali dan Asam terhadap Karakteristik Mutu Bakto Agar ....(Muhamad Darmawan et al.,)

Hasil analisis menunjukkan kandungan sulfat bakto agar tidak dipengaruhi oleh praperlakuan $\mathrm{NaOH}$, $\mathrm{CH}_{3} \mathrm{COOH}$, dan interaksi antara keduanya $(p>0,05)$. Penelitian yang dilakukan oleh Fleire-Pelegrin dan Murano (2005) menunjukkan agar yang tidak diberi perlakuan alkali memiliki kadar sulfat yang tinggi yaitu sebesar $5,3 \%$ dan kandungan ester sulfat pada agar tetap stabil walaupun diberi perlakuan $\mathrm{NaOH} 7 \%$. Kekuatan gel dari agar sangat dipengaruhi oleh kadar sulfat yang dimilikinya. Hal ini disebabkan sifat hidrofilik pada sulfat sehingga kadar sulfat dalam agar menurunkan nilai kekuatan gel dari agar tersebut (Santika et al., 2014). Agar dari rumput laut Gracilaria edulis yang diekstrak dengan praperlakuan $\mathrm{NaOH} 6 \%$ memiliki kadar sulfat 2,1\% dan kekuatan gel $340 \mathrm{~g} /$ $\mathrm{cm}^{2}$. Kadar sulfat bakto agar yang dilakukan oleh Chirapart, Munkit, dan Lewmanomont (2006) sebesar $1,54 \%$, sehingga bakto agar yang diekstrak dengan praperlakuan $\mathrm{NaOH} 4 \%$ dan $\mathrm{CH}_{3} \mathrm{COOH} 1 \%$ memiliki nilai yang sama dengan kadar sulfat bakto agar tersebut.

\section{Gugus fungsi}

Hasil spektrum gugus fungsi bakto agar dapat dilihat pada Gambar 5 dan data spektrum gugus fungsi bakto agar disajikan pada Tabel 3.

Gugus fungsi yang diamati pada bakto agar yaitu $\mathrm{CH}_{2}$, sulfat, 3,6 anhidrogalaktosa, 1,3 $\beta$-D galaktosa piranosil, dan ikatan yang menunjukkan karakteristik agar. Hasil pengujian gugus fungsi bakto agar memperlihatkan keseluruhan sampel memiliki gugus senyawa kimia yang sama dengan bilangan gelombang yang tidak jauh berbeda dengan bakto agar komersial. Gugus $\mathrm{CH}_{2}$ pada bakto agar terserap pada bilangan gelombang $2918,56 \mathrm{~cm}^{-1}$ sampai 2926,95 $\mathrm{cm}^{-1}$. Penelitian yang dilakukan oleh Guerrero,

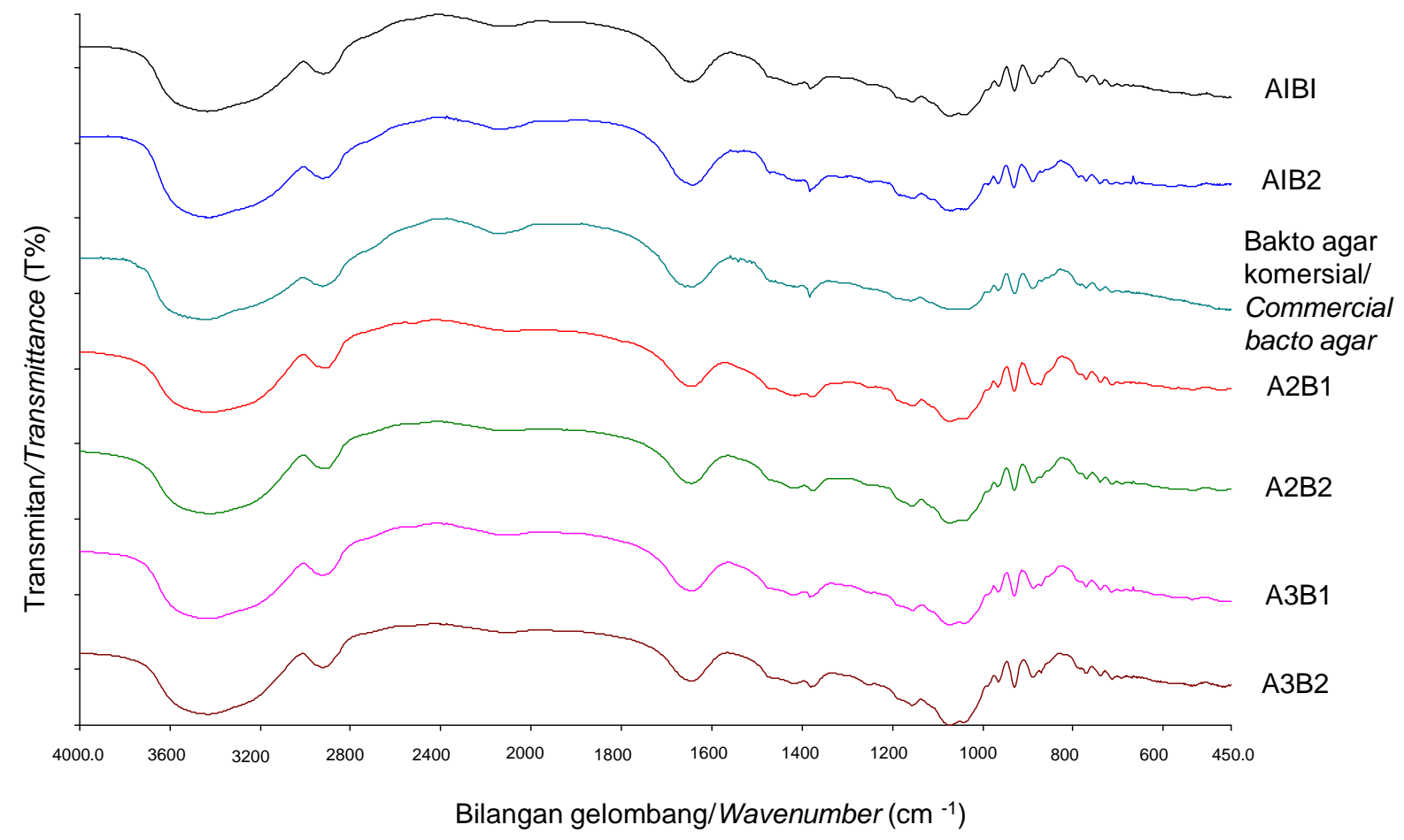

Keterangan/Note:

Nilai $Y$ axis untuk masing-masing spektrum digeser untuk memperlihatkan kemiripan struktur spektrum/ $Y$ axis value for each spectrum is shifted to show similarity in spectrum structure

A1B1: $\mathrm{NaOH} 4 \%$ dan $\mathrm{CH}_{3} \mathrm{COOH} \mathrm{0,5 \% /4 \%} \mathrm{NaOH}$ and $0.5 \% \mathrm{CH}_{3} \mathrm{COOH}$

A1B2: $\mathrm{NaOH} 4 \%$ dan $\mathrm{CH}_{3} \mathrm{COOH} 1 \% / 4 \% \mathrm{NaOH}$ and $1 \% \mathrm{CH}_{3} \mathrm{COOH}$

A2B1: $\mathrm{NaOH} 5 \%$ dan $\mathrm{CH}_{3} \mathrm{COOH} 0,5 \% / 5 \% \mathrm{NaOH}$ and $0.5 \% \mathrm{CH}_{3} \mathrm{COOH}$

A2B2: $\mathrm{NaOH} 5 \%$ dan $\mathrm{CH}_{3} \mathrm{COOH} 1 \% / 5 \% \mathrm{NaOH}$ and $1 \% \mathrm{CH}_{3} \mathrm{COOH}$

A3B1: $\mathrm{NaOH} 6 \%$ dan $\mathrm{CH}_{3} \mathrm{COOH} 0,5 \% / 6 \% \mathrm{NaOH}$ and $0.5 \% \mathrm{CH}_{3} \mathrm{COOH}$

A3B2: $\mathrm{NaOH} 6 \%$ dan $\mathrm{CH}_{3} \mathrm{COOH} 1 \% / 6 \% \mathrm{NaOH}$ and $1 \% \mathrm{CH}_{3} \mathrm{COOH}$

Gambar 5. Spektrum FT-IR bakto agar

Figure 5. Spectrum FT-IR of bacto agar 
Tabel 3. Data spektrum FTIR bakto agar Gelidium sp.

Table 3. Spectrum data of bacto agar of Gelidium $s p$.

\begin{tabular}{|c|c|c|c|c|c|c|c|}
\hline \multirow{2}{*}{$\begin{array}{l}\text { Gugus senyawa kimia/ } \\
\text { Chemical compound group }\end{array}$} & \multicolumn{6}{|c|}{ Perlakuan/Treatments } & \multirow{2}{*}{$\begin{array}{l}\text { Bakto agar } \\
\text { Bacto agar }\end{array}$} \\
\hline & A1B1 & A2B2 & A2B1 & A2B2 & A3B1 & A3B2 & \\
\hline$-\mathrm{CH}_{2}$ & 2925.15 & 2918.56 & 2921.25 & 2921.14 & 2923.05 & 2923.55 & 2926.95 \\
\hline Sulfat/Sulfate & 1383.75 & 1383.86 & 1378.53 & 1377.13 & 1382.94 & 1383.65 & 1384.05 \\
\hline 3,6 AG/3.6 AG & 931.85 & 931.95 & 931.43 & 931.33 & 931.44 & 931.15 & 930.46 \\
\hline $\begin{array}{l}1,3 \beta \text {-D galaktosa piranosil/ } \\
1,3 \beta-D \text { galactose pyranosyl }\end{array}$ & 891.05 & 871.17 & 872.24 & 871.94 & 871.95 & 871.95 & 885.50 \\
\hline \multirow{3}{*}{$\begin{array}{l}\text { Karakteristik ikatan agar/ } \\
\text { Agar bond characteristic }\end{array}$} & 772.90 & 771.86 & 771.96 & 771.84 & 772.15 & 772.50 & 772.40 \\
\hline & 740.05 & 741.56 & 740.83 & 740.86 & 741.52 & 740.35 & 742.05 \\
\hline & & 717.80 & 714 & 714,94 & 715.51 & 714.56 & 717.90 \\
\hline
\end{tabular}

Keterangan/Note :

A1B1: $\mathrm{NaOH} 4 \%$ dan $\mathrm{CH}_{3} \mathrm{COOH} 0,5 \% / 4 \% \mathrm{NaOH}$ and $0.5 \% \mathrm{CH}_{3} \mathrm{COOH}$

A1B2: $\mathrm{NaOH} 4 \%$ dan $\mathrm{CH}_{3} \mathrm{COOH} 1 \% / 4 \% \mathrm{NaOH}$ and $1 \% \mathrm{CH}_{3} \mathrm{COOH}$

A2B1: $\mathrm{NaOH} 5 \%$ dan $\mathrm{CH}_{3} \mathrm{COOH} 0,5 \% / 5 \% \mathrm{NaOH}$ and $0.5 \% \mathrm{CH}_{3} \mathrm{COOH}$

A2B2: $\mathrm{NaOH} 5 \%$ dan $\mathrm{CH}_{3} \mathrm{COOH} 1 \% / 5 \% \mathrm{NaOH}$ and $1 \% \mathrm{CH}_{3} \mathrm{COOH}$

A3B1: $\mathrm{NaOH} 6 \%$ dan $\mathrm{CH}_{3} \mathrm{COOH} 0,5 \% / 6 \% \mathrm{NaOH}$ and $0.5 \% \mathrm{CH}_{3} \mathrm{COOH}$

A3B2: $\mathrm{NaOH} 6 \%$ dan $\mathrm{CH}_{3} \mathrm{COOH} 1 \% / 6 \% \mathrm{NaOH}$ and $1 \% \mathrm{CH}_{3} \mathrm{COOH}$

Etxabide, Leceta, Pe nalba, dan de La Caba (2014) menunjukkan penyerapan ikatan $\mathrm{CH}_{2}$ pada agar Gelidium sesquipedale terjadi pada bilangan gelombang $2932 \mathrm{~cm}^{-1}$.

Ikatan sulfat bakto agar terserap pada bilangan gelombang $1377,13 \mathrm{~cm}^{-1}$ sampai $1383,86 \mathrm{~cm}^{-1}$. Bilangan gelombang $1370 \mathrm{~cm}^{-1}$ dan $1243 \mathrm{~cm}^{-1}$ menunjukkan adanya ikatan sulfat (Guerrero et al., 2014). Gugus kimia 1,3 $\beta$-D galaktosa piranosil bakto agar terserap pada bilangan gelombang $871,17 \mathrm{~cm}^{-1}$ sampai $891,05 \mathrm{~cm}^{-1}$. Ikatan $\beta$-D galaktosa piranosil agar terlihat pada penyerapan $891 \mathrm{~cm}^{-1}$ (Guerrero et al., 2014; Gómez-Ordóñez \& Rupérez, 2011). Gugus fungsi 3,6-anhidrogalaktosa ditandai pada bilangan gelombang $930 \mathrm{~cm}^{-1}$ (Al-Nahdi et al., 2015). Spektrum pada range berkisar antara $700 \mathrm{~cm}^{-1}$ dan $800 \mathrm{~cm}^{-1}$ menunjukkan ikatan yang merupakan karakteristik agar (Gómez-Ordóñez \& Rupérez, 2011).

\section{Rendemen}

Rendemen dari bakto dihitung berdasarkan perbandingan berat bakto agar yang diperoleh terhadap berat kering rumput laut Gelidium sp. yang digunakan (Murdinah et al., 2008). Hasil analisis rendemen bakto agar disajikan pada Gambar 6 .

Hasil analisis menunjukkan bahwa rendemen berkurang dengan peningkatan konsentrasi $\mathrm{NaOH}$ yang digunakan. Penelitian Meena, Prasad, Ganesan, dan Siddhanta (2008), Sahu dan Sahoo (2013) serta Yarnpakdee et al. (2015) memperlihatkan hasil yang sama yaitu nilai rendemen agar semakin turun seiring dengan meningkatnya konsentrasi $\mathrm{NaOH}$ yang digunakan, hal ini disebabkan karena pada saat proses praperlakuan alkali berlangsung, agar akan ikut terekstrak dan terbuang pada saat proses pencucian rumput laut setelah tahapan praperlakuan alkali. (Darmawan et al., 2006). Praperlakuan $\mathrm{NaOH} 3 \%$ yang diikuti dengan praperlakuan asam sulfat memberikan nilai rendemen sebesar 13,3\% (OrdunaRojas et al., 2008). Penelitian yang dilakukan Rodríguez-Montesinos et al. (2013) menunjukkan agar Gracilaria veleroae yang diekstrak dengan praperlakuan $\mathrm{NaOH} 3 \%$ dan $\mathrm{CH}_{3} \mathrm{COOH} 0,025 \%$ menghasilkan rendemen tertinggi sebesar $12,1 \%$. Penggunaan suhu tinggi pada praperlakuan alkali (80$100^{\circ} \mathrm{C}$ ) dapat menurunkan rendemen agar (FleirePelegrin et al., 2005) karena terjadi degradasi polisakarida (Praiboon et al., 2006).

Analisis menunjukkan rendemen bakto agar dipengaruhi oleh praperlakuan $\mathrm{NaOH}$ dan interaksi antara $\mathrm{NaOH}$ dan $\mathrm{CH}_{3} \mathrm{COOH}(\mathrm{p}<0,05)$. Rendemen bakto agar yang diekstrak dengan $\mathrm{NaOH} 4 \%$ dan $\mathrm{CH}_{3} \mathrm{COOH} 1 \%$ berbeda nyata terhadap praperlakuan lainnya. Praperlakuan $\mathrm{NaOH} 3 \%$ yang diikuti dengan praperlakuan asam sulfat memberikan nilai rendemen sebesar 13,3\% (Orduña-Rojas et al., 2008).

Penambahan $\mathrm{NaOH}$ dan $\mathrm{CH}_{3} \mathrm{COOH}$ pada proses ekstraksi mempengaruhi nilai rendemen bakto agar. Penambahan $\mathrm{NaOH}$ pada proses ekstraksi agar memudahkan proses penarikan ekstrak agar pada saat ditambahkan bahan kimia yang bersifat asam. $\mathrm{Hal}$ ini dapat berpengaruh terhadap nilai rendemen 


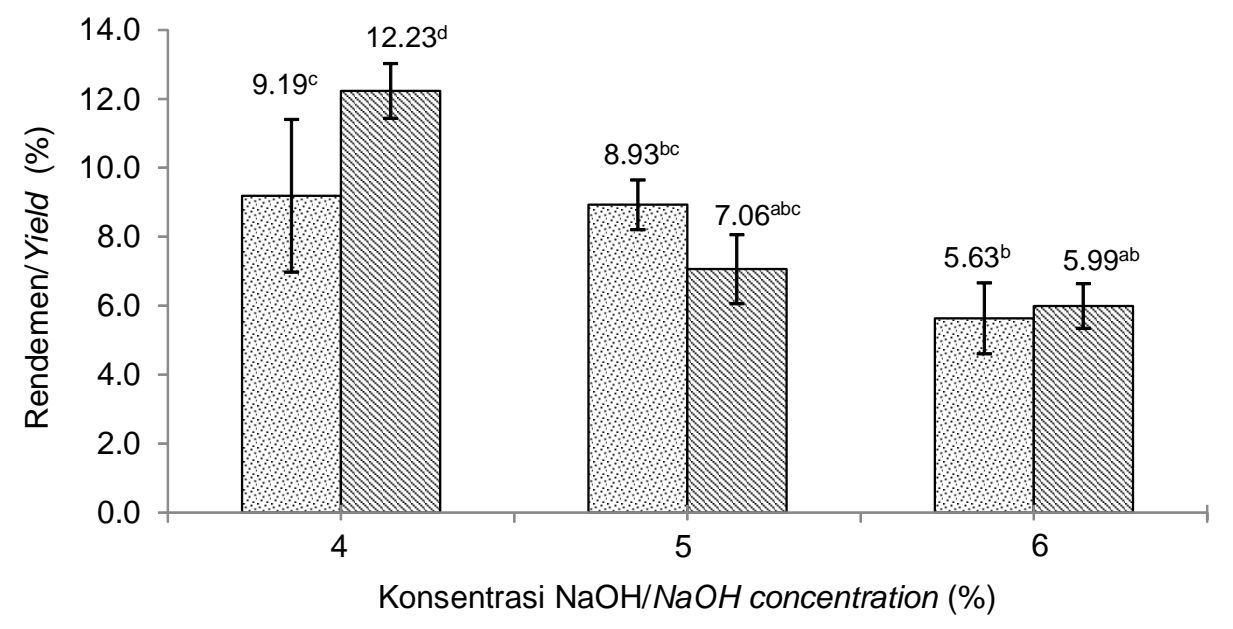

Keterangan/Note: Huruf yang sama menunjukkan tidak berbeda nyata/The same letters indicate no significant difference.

Gambar 6. Rendemen bakto agar.

Figure 6. Yield of bacto agar

yang didapatkan (Santika et al., 2014). Asam yang digunakan dalam proses praperlakuan dapat berupa asam lemah yang berfungsi untuk menetralkan residu alkali (McHugh, 2003). Penambahan $\mathrm{CH}_{3} \mathrm{COOH}$ pada proses ekstraksi agar dapat meningkatkan rendemen agar. Penambahan $\mathrm{CH}_{3} \mathrm{COOH}$ bertujuan untuk melunakkan serta memecah dinding sel rumput laut sehingga memudahkan proses difusi gel agar ke dalam pelarut (Distantina et al., 2008).

\section{Kekuatan gel}

Pada Gambar 7 ditampilkan kekuatan gel bakto agar hasil ekstraksi dari Gellidium sp. yang berkisar antara 1016,60-1464,98 g/ $\mathrm{cm}^{2}$.

Kekuatan gel bakto agar tidak dipengaruhi oleh praperlakuan $\mathrm{NaOH}$ dan $\mathrm{CH}_{3} \mathrm{COOH}$, dan interaksi antara keduanya $(p>0,05)$. Penambahan alkali dalam proses ekstraksi dapat menyebabkan perubahan

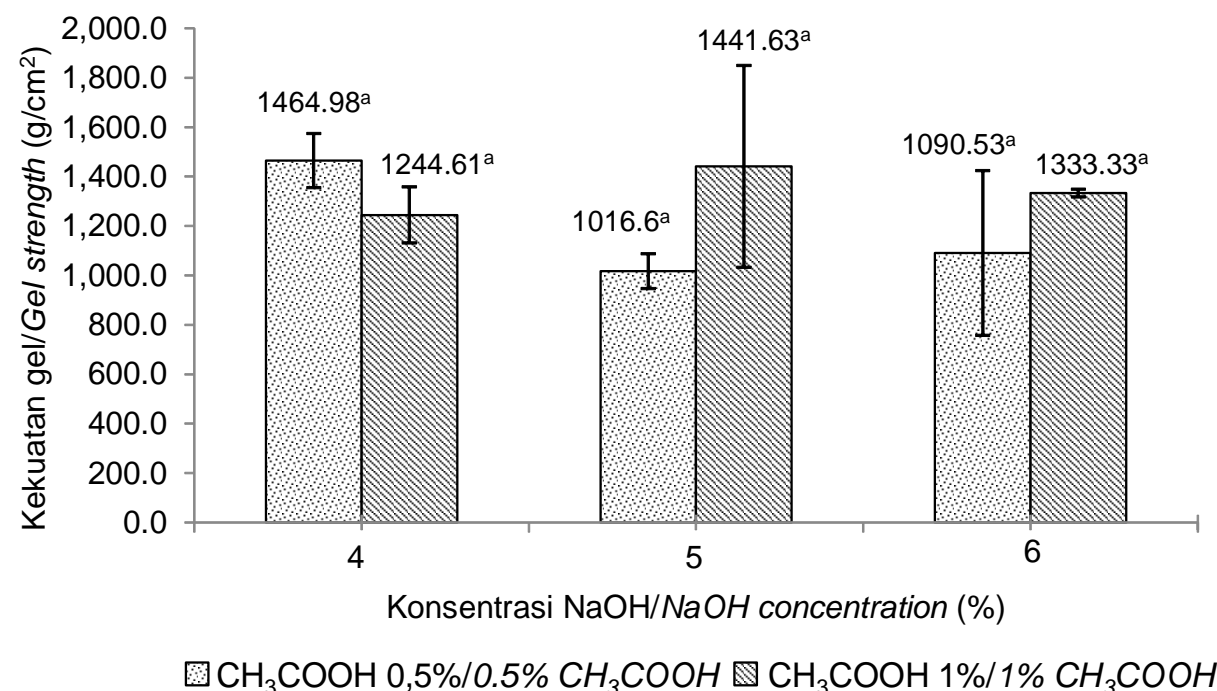

Keterangan/Note: Huruf yang sama menunjukkan tidak berbeda nyata/The same letters indicate no significant difference.

Gambar 7. Kekuatan gel bakto agar.

Figure 7. Gel strength of bacto agar 
kimia dalam agar (pembentukan 3,6-anhidrogalaktopiranosa) yang dapat meningkatkan kekuatan gel (Knudsen, Marcel, \& Anne, 2015). Proses pembentukan gel terjadi karena adanya interaksi antar struktur heliks. Tiga atom hydrogen yang terdapat pada residu 3,6 anhidro-l-galaktosa memaksa molekul yang ada membentuk struktur heliks (Murdinah, Apriani, Nurhayati, \& Subaryono, 2012). Agar dengan praperlakuan $\mathrm{NaOH} 5 \%$ dan $\mathrm{H}_{2} \mathrm{SO}_{4} 0,025 \%$ memiliki nilai kekuatan gel sebesar $482 \mathrm{~g} / \mathrm{cm}^{2}$ (Yarnpakdee et al., 2015). Agar dari Gracilaria corticatayang diekstrak dengan $\mathrm{NaOH} 5 \%$ menghasilkan kekuatan gel tertinggi yaitu sebesar 634,2 g/cm² (Yousefi et al., 2013).

Spesifikasi mutu kekuatan gel bakto agar berdasarkan Supreme Marine Chemicaluntuk reguler grade sebesar $400-500 \mathrm{~g} / \mathrm{cm}^{2}$, standard grade 500 sampai $600 \mathrm{~g} / \mathrm{cm}^{2}$, dan premium grade di atas $600 \mathrm{~g} /$ $\mathrm{cm}^{2}$ (Kumala et al., 2013). Bakto agar dengan konsentrasi $\mathrm{NaOH} 4 \%$ dan $\mathrm{CH}_{3} \mathrm{COOH} \mathrm{0,5 \%}$ merupakan konsentrasi terpilih karena menghasilkan nilai kekuatan gel yang tinggi dengan konsentrasi yang rendah. Nilai kekuatan gel bakto agar yang dihasilkan masuk ke dalam grade premium. Kekuatan gel dipengaruhi oleh kadar 3,6-anhidrogalaktosa, di mana semakin tinggi kadar 3,6-anhidrogalaktosa maka semakin tinggi kekuatan gel yang dihasilkan. Tingginya kadar sulfat yang dimiliki dapat menyebabkan semakin rendahnya kekuatan gel yang dihasilkan karena sulfat memiliki sifat yang hidrofilik sehingga dengan tingginya kadar sulfat yang terdapat dalam agar akan menyebabkan kekuatan gel agar lebih rendah (Santika et al., 2014). Bakto agar dari Gelidium regidum dengan kadar sulfat 3,6 sampai $3,98 \%$ memiliki kekuatan gel berkisar antara 115,8 sampai $670,72 \mathrm{~g} / \mathrm{cm}^{2}$ (Murdinah et al., 2008). Kadar sulfat bakto agar tesebut lebih tinggi dibandingkan dengan kadar sulfat bakto agar hasil penelitian ini, hal ini membuat kekuatan gel pada penelitian ini jauh lebih tinggi. Kekuatan gel dari agar dapat dipengaruhi oleh produksi polisakarida pada rumput laut yang sangat tergantung pada kondisi lingkungan budidaya rumput laut (Santika et al., 2014).

\section{Viskositas}

Hasil analisis viskositas bakto agar dapat dilihat pada Gambar 8, viskositas bakto agar yang diperoleh berkisar antara 26,2-47,5 cP.

Hasil analisis viskositas bakto agar menunjukkan praperlakuan $\mathrm{NaOH}, \mathrm{CH}_{3} \mathrm{COOH}$, dan interaksi keduanya tidak berpengaruh $(p>0,05)$ terhadap viskositas bakto agar. Bakto agar dengan praperlakuan $\mathrm{NaOH} 4 \%$ dan $\mathrm{CH}_{3} \mathrm{COOH} 0,5 \%$ merupakan konsentrasi terpilih sebab tidak berbeda nyata dengan konsentrasi lainnya dan merupakan konsentrasi terendah dengan nilai viskositas yang tinggi. Gelidium sesquipedale memiliki nilai viskositas sebesar 11,11 cP (Nil, Ali-Mehidi, Zellal, \& Abi-Ayad, 2016). Nilai viskositas agar yang diekstrak dari Gracilaria verucossa dengan praperlakuan $\mathrm{NaOH}$ pada kosentrasi berbeda berkisar antara 17,52-18,96 cP (Santika et al., 2014). Tingginya gaya gesek yang terdapat di dalam agar yang memiliki kekuatan gel

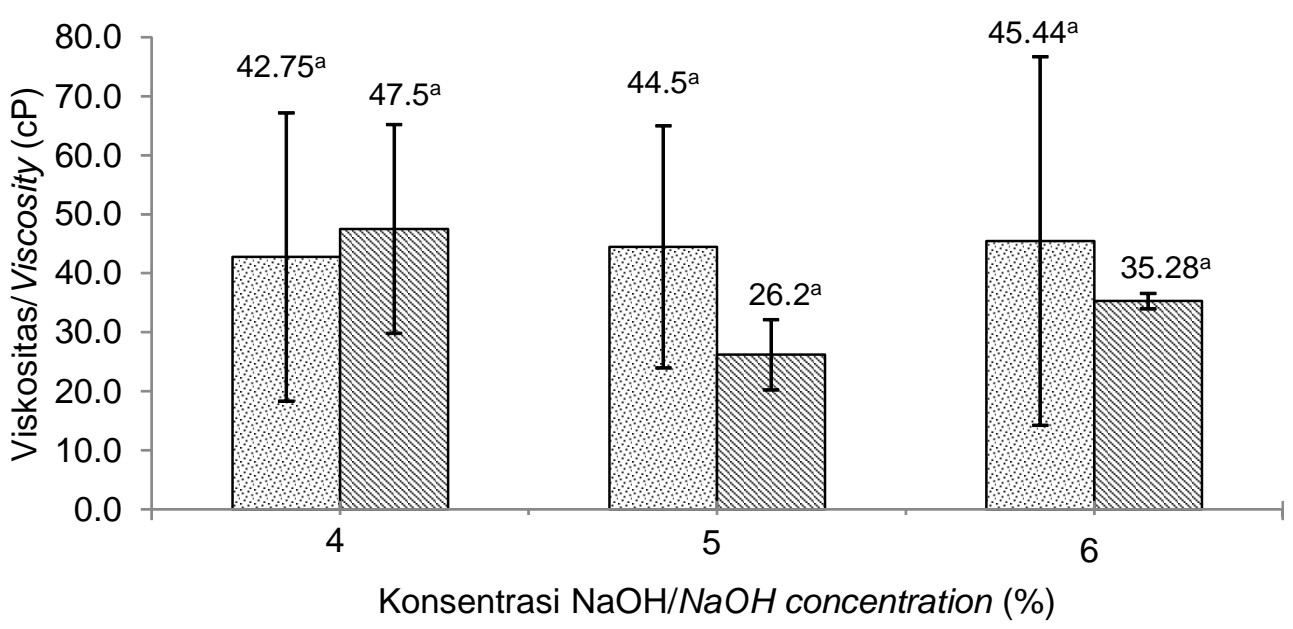

图 $\mathrm{CH}_{3} \mathrm{COOH} \mathrm{0,5 \% /0.5 \%} \mathrm{CH}_{3} \mathrm{COOH} \otimes \mathrm{CH}_{3} \mathrm{COOH} 1 \% / 1 \% \mathrm{CH}_{3} \mathrm{COOH}$

Keterangan/Note: Huruf yang sama menunjukkan tidak berbeda nyata/The same letters indicate no significant difference.

Gambar 8. Viskositas bakto agar

Figure 8. Viscosity of bacto agar 
yang tinggi akan menyebabkan tingginya nilai viskositas yang dimiliki (Santika et al., 2014). Kekuatan gel bakto agar pada penelitian ini sangat tinggi sehingga viskositas yang dihasilkan juga tinggi.

\section{Titik jendal}

Titik jendal bakto agar bekisar antara 17,00-23,75 ${ }^{\circ} \mathrm{C}$, hasil pengujian titik jendal bakto agar dapat dilihat pada Gambar 9.

Titik jendal bakto agar dipengaruhi oleh praperlakuan $\mathrm{NaOH}$, praperlakuan $\mathrm{CH}_{3} \mathrm{COOH}$, dan interaksi antara keduanya $(p<0,05)$. Titik jendal bakto agar yang diekstrak dengan praperlakuan $\mathrm{NaOH} 5 \%$ dan $\mathrm{CH}_{3} \mathrm{COOH} 0,5 \%$ tidak berbeda nyata dengan praperlakuan $\mathrm{NaOH} 4 \%$ dan $\mathrm{CH}_{3} \mathrm{COOH} 1 \%$, namun berbeda nyata terhadap praperlakuan lainnya. Spesifikasi mutu titik jendal bakto agar berdasarkan Supreme Marine Chemical pada semua grade menunjukkan nilai $38^{\circ} \mathrm{C}$ sampai $40{ }^{\circ} \mathrm{C}$ (Kumala et al., 2013). Bakto agar dengan konsentrasi $\mathrm{NaOH} 5 \%$ dan $\mathrm{CH}_{3} \mathrm{COOH} 1 \%$ merupakan konsentrasi terpilih karena memiliki nilai yang tidak berbeda nyata terhadap $\mathrm{NaOH} 6 \%$ dan $\mathrm{CH}_{3} \mathrm{COOH} 1 \%$ yang memiliki suhu yang lebih mendekati standar.

Agar dari Glacilaria crassa yang diekstrak dengan praperlakuan $\mathrm{NaOH} 8 \%$ memiliki titik jendal sebesar $35^{\circ} \mathrm{C}$ (Meena et al., 2008). Agar yang memiliki titik jendal yang rendah dapat digunakan untuk aplikasi bakteriologis dan bioteknologi (Meena et al., 2008).
Rendahnya titik jendal bakto agar yang dihasilkan disebabkan oleh tingginya kadar sulfat. Konversi Lgalaktosa-6-sulfat menjadi 3,6-anhidro-L-galaktosa meningkatkan kekuatan gel dan suhu transisi gel (Fleire-Pelegrin et al., 2005). Adanya ester sulfat pada atom karbon yang keenam dari L-galaktosa (C6) akan menghambat proses pembentukan gel bakto agar. Rantai polimer akan membentuk suatu tekukan akibat adanya ester sulfat tersebut (Murdinah et al., 2008).

\section{Titik leleh}

Hasil pengukuran titik leleh bakto agar ditampilkan pada Gambar 10, rata-rata titik leleh bakto agar yang diperoleh dari penelitian ini berkisar antara $88,25-95,00^{\circ} \mathrm{C}$.

Titik leleh bakto agar dipengaruhi oleh praperlakuan $\mathrm{NaOH}$ dan interaksi antara praperlakuan $\mathrm{NaOH}$ dan $\mathrm{CH}_{3} \mathrm{COOH}(\mathrm{p}<0,05)$. Titik leleh bakto agar yang diekstrak dengan praperlakuan $\mathrm{NaOH} 5 \%$ dan $\mathrm{CH}_{3} \mathrm{COOH} 0,5 \%$ berbeda nyata terhadap praperlakuan lainnya sehingga menjadi praperlakuan terpilih. Bakto agar yang dihasilkan memiliki titik leleh yang lebih tinggi dibandingkan dengan bakto agar hasil penelitian Murdinah et al (2008) yaitu $67-77^{\circ} \mathrm{C}$ dan standar Supreme Marine Chemical yaitu $78-80^{\circ} \mathrm{C}$ (Kumala et al., 2013). Titik leleh dan kekuatan gel pada agar yang diekstrak dengan alkali memiliki korelasi positif (FleirePelegrin et al., 2005). Tingginya titik leleh mengindikasikan bahwa gel dari agar tersebut lebih

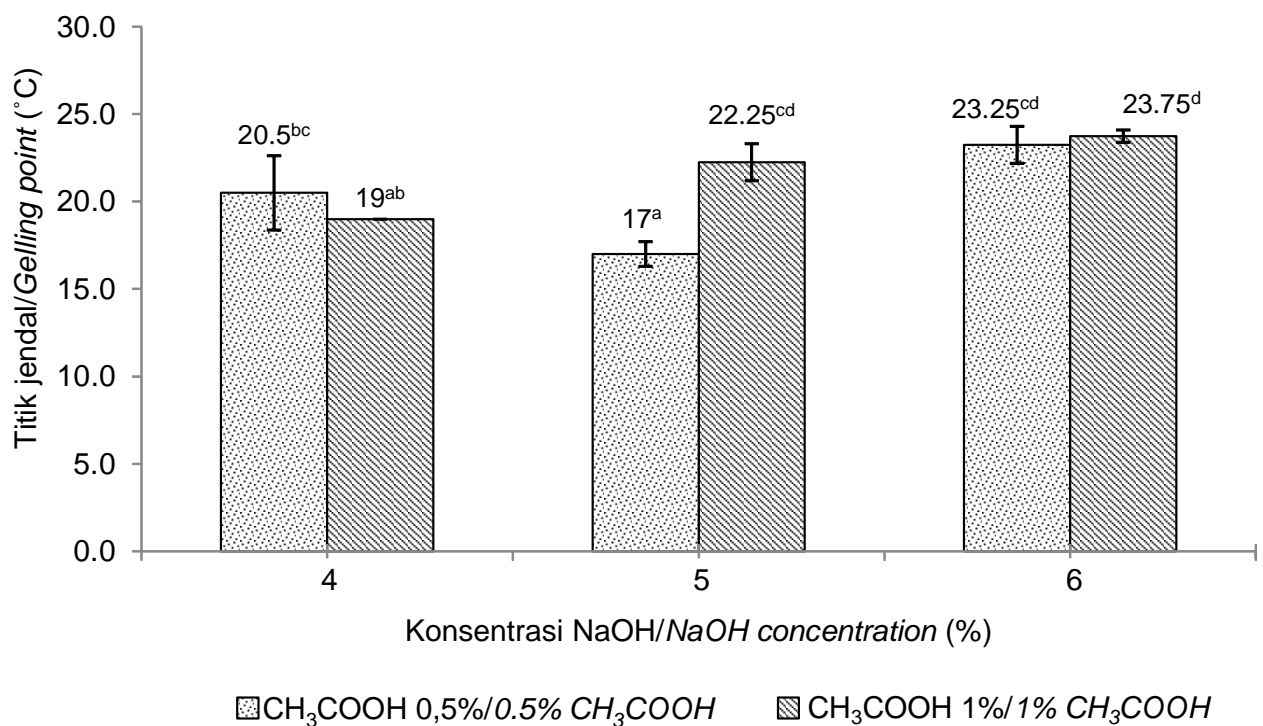

Keterangan/Note: Huruf yang sama menunjukkan tidak berbeda nyata/The same letters indicate no significant difference.

Gambar 9. Titik jendal bakto agar

Figure 9. Gelling point of bacto agar 


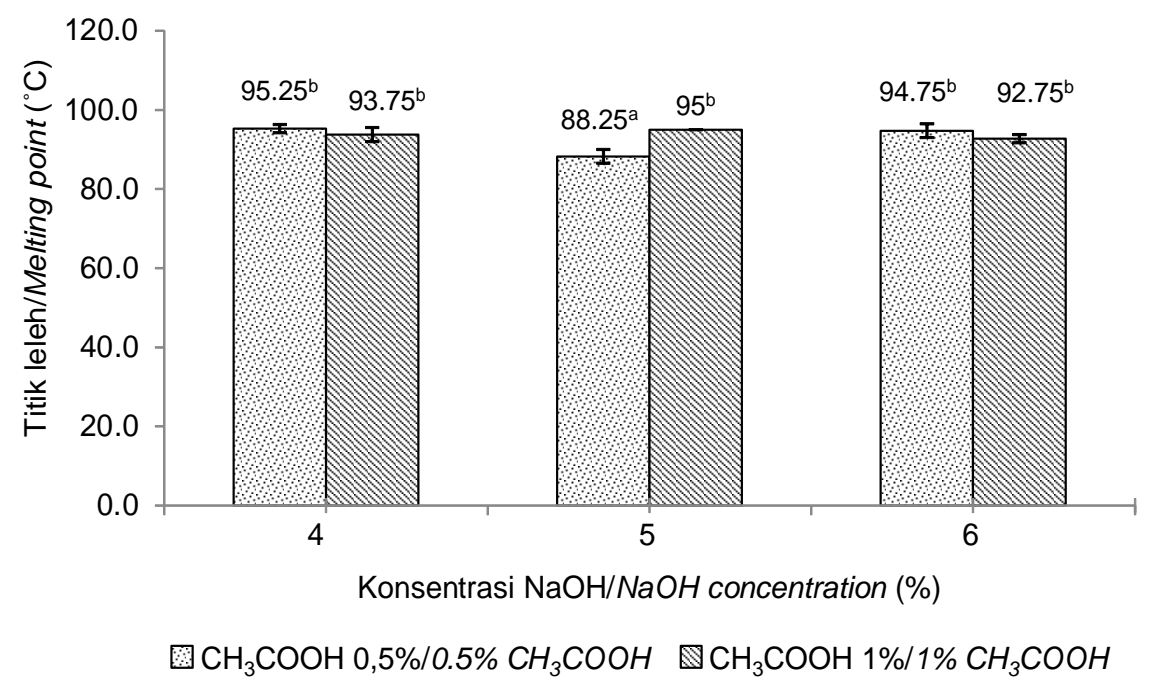

Keterangan/Note: Huruf yang sama menunjukkan tidak berbeda nyata/The same letters indicate no significant difference.

Gambar 10. Nilai titik leleh bakto agar

Figure 10. Melting point of bacto agar

stabil sebab membutuhkan energi yang besar untuk memecah jaringan agar (Yarnpakdee et al., 2015). Penelitian yang dilakukan oleh Villanueva et al. (2010) menunjukkan titik leleh akan semakin meningkat seiring dengan tingginya konsentrasi alkali. Ekstrak agar dari Gracilaria crassissima memiliki titik leleh tertinggi yaitu sebesar $93^{\circ} \mathrm{C}$ pada perlakuan $\mathrm{NaOH}$ $7 \%$ (Fleire-Pelegrin \& Murano, 2005). Penelitian yang dilakukan oleh Ganesan dan Rao (2004) menunjukkan praperlakuan alkali dan asam memberikan titik leleh yang tinggi pada Gracilaria edulis $\left(82,5^{\circ} \mathrm{C}\right)$.

\section{Sineresis}

Sineresis merupakan jumlah air yang hilang dari gel agar dan menunjukkan ketidakstabilan jaringan gel pada saat penyimpanan (Yarnpakdee et al., 2015). Nilai sineresis bakto agar dapat dilihat pada Gambar 11.

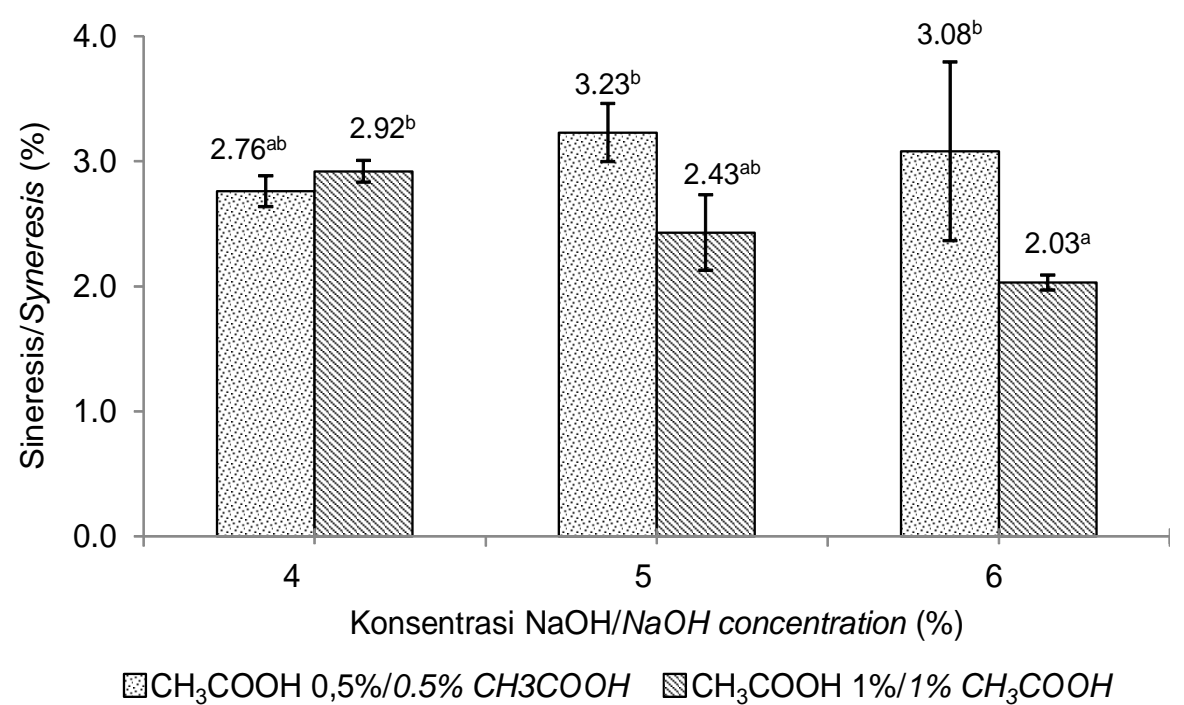

Keterangan/Note: Huruf yang sama menunjukkan tidak berbeda nyata/The same letters indicate no significant difference.

Gambar 11. Persentase sineresis bakto agar

Figure 11. Syneresis percentage of bacto agar 
Interaksi antara praperlakuan $\mathrm{NaOH}$ dan $\mathrm{CH}_{3} \mathrm{COOH}$ memberikan pengaruh terhadap sineresis bakto agar $(p<0,05)$. Titik leleh bakto agar yang diekstrak dengan praperlakuan $\mathrm{NaOH} 6 \%$ dan $\mathrm{CH}_{3} \mathrm{COOH} 1 \%$ tidak berbeda nyata terhadap praperlakuan $\mathrm{NaOH} 4 \%$ dan $\mathrm{CH}_{3} \mathrm{COOH} 0,5 \%$, serta praperlakuan $\mathrm{NaOH} 5 \%$ dan $\mathrm{CH}_{3} \mathrm{COOH} 1 \%$, namun berbeda nyata dengan praperlakuan lainnya. Bakto agar dengan praperlakuan $\mathrm{NaOH} 5 \%$ dan $\mathrm{CH}_{3} \mathrm{COOH} 1 \%$ merupakan praperlakuan terpilih sebab memiliki nilai lebih rendah dibandingkan dengan $\mathrm{NaOH} 6 \%$ dan $\mathrm{CH}_{3} \mathrm{COOH} 1 \%$. Nilai sineresis agar dengan praperlakuan $\mathrm{NaOH}$ dan $\mathrm{H}_{2} \mathrm{SO}_{4}$ berkisar antara 1,05 sampai 1,18\% (Yarnpakdee et al., 2015).

Penelitian yang dilakukan Villanueva et al. (2010) menunjukkan agar yang tidak diberi perlakuan $\mathrm{NaOH}$ memiliki nilai sineresis lebih besar dibandingkan dengan agar yang diberi perlakuan $\mathrm{NaOH}$. Nilai sineresis untuk agar tanpa perlakuan $\mathrm{NaOH}$ sebesar $16 \%$ sementara agar dengan perlakuan $\mathrm{NaOH} 5 \%$ sebesar $12,3 \%$. Nilai ini lebih besar dibandingkan dengan indeks sineresis pada bakto agar yang dihasilkan. Sineresis agar berkaitan dengan kekuatan gel (Yarnpakdee et al., 2015) dan kadar sulfat (Lee, Namasivayam \& Ho, 2014). Tingginya nilai sineresis mengindikasikan rendahnya kestabilan polimer gel agar saat penyimpanan (Lee et al., 2014).

\section{Angka lempeng total}

Pengujian mikrobiologi bertujuan untuk menguji kemampuan bakto agar setelah ditambah media pertumbuhan lainnya untuk menumbuhkan bakteri (Kumala et al., 2013). Pengujian mikrobiologi pada penelitian ini menggunakan bakto agar hasil ektraksi dan bakto agar merek OXOID. Hasil pengujian mikrobiologi berupa perhitungan ALT pada ikan segar dapat dilihat pada Tabel 3.

Hasil analisis ALT bakto agar menunjukkan praperlakuan $\mathrm{NaOH}$, perlakuan $\mathrm{CH}_{3} \mathrm{COOH}$, serta interaksi keduanya tidak berpengaruh terhadap hasil ALT. Nilai ALT pada bakto agar hasil ektraksi tidak jauh berbeda dengan nilai ALT pada bakto agar komersial, hal ini mengindikasikan bakto agar yang diekstrak dengan praperlakuan berbeda memiliki kemampuan menumbuhkan bakteri dengan nilai ALT yang tidak berbeda nyata dengan bakto agar komersial. Bakto agar dengan praperlakuan $\mathrm{NaOH} 4 \%$ dan $\mathrm{CH}_{3} \mathrm{COOH}$ 0,5\% merupakan praperlakuan terpilih sebab memiliki nilai ALT yang tidak berbeda dengan bakto agar komersial dan merupakan konsentrasi terendah. Standar jumlah koloni pada ikan segar yaitu $2 \times 10^{5} \mathrm{cfu} / \mathrm{mL}$ (BSN, 2006a) sehingga pengujian ALT pada ikan segar menggunakan bakto agar hasil ekstraksi telah memenuhi standar SNI. Pengujian ALT bakto agar Gelidium rigidium adalah $3,1 \times 10^{9} \mathrm{cfu} / \mathrm{mL}$ (Murdinah et al., 2008).

\section{KESIMPULAN}

Praperlakuan $\mathrm{NaOH}$ dan $\mathrm{CH}_{3} \mathrm{COOH}$ dengan konsentrasi berbeda berpengaruh terhadap rendemen, kadar air, kadar abu, titik jendal, titik leleh, dan sineresis pada bakto agar yang dihasilkan. Hasil analisis ALT bakto agar menunjukkan praperlakuan $\mathrm{NaOH}$, praperlakuan $\mathrm{CH}_{3} \mathrm{COOH}$, serta interaksi keduanya tidak berpengaruh terhadap hasil ALT dan memiliki kemampuan menumbuhkan bakteri dengan nilai ALT yang tidak jauh berbeda dengan bakto agar komersial. Perlakuan terbaik diperoleh dari praperlakuan dengan konsentrasi $\mathrm{NaOH} 4 \%$ dan

Tabel 4. Hasil perhitungan angka lempeng total pada ikan segar menggunakan bakto agar perlakuan Table 4. Total plate count for fresh fish using bacto agar treatment

\begin{tabular}{lc}
\hline \multicolumn{1}{c}{ Perlakuan/Treatment } & $\begin{array}{c}\text { Nilai ALT/Total Plate } \\
\text { Count (cfu/mL) }\end{array}$ \\
\hline $\mathrm{NaOH} 4 \%$ dan $\mathrm{CH}_{3} \mathrm{COOH} 0,5 \% / 4 \% \mathrm{NaOH}$ and $0,5 \% \mathrm{CH}_{3} \mathrm{COOH}$ & $1.9 \times 10^{4 a}$ \\
$\mathrm{NaOH} 4 \%$ dan $\mathrm{CH}_{3} \mathrm{COOH} 1 \% / 4 \% \mathrm{NaOH}$ and $1 \% \mathrm{CH}_{3} \mathrm{COOH}$ & $2.8 \times 10^{4 \mathrm{a}}$ \\
$\mathrm{NaOH} 5 \%$ dan $\mathrm{CH}_{3} \mathrm{COOH} 0,5 \% / 5 \% \mathrm{NaOH}$ and $0,5 \% \mathrm{CH}_{3} \mathrm{COOH}$ & $3.8 \times 10^{4 \mathrm{a}}$ \\
$\mathrm{NaOH} 5 \%$ dan $\mathrm{CH}_{3} \mathrm{COOH} 1 \% / 5 \% \mathrm{NaOH}$ and $1 \% \mathrm{H}_{3} \mathrm{COOH}$ & $2.2 \times 10^{4 \mathrm{a}}$ \\
$\mathrm{NaOH} 6 \%$ dan $\mathrm{CH}_{3} \mathrm{COOH} 0,5 \% / 6 \% \mathrm{NaOH}$ and $0,5 \% \mathrm{CH}_{3} \mathrm{COOH}$ & $1.7 \times 10^{4 \mathrm{a}}$ \\
$\mathrm{NaOH} 6 \%$ dan $\mathrm{CH}_{3} \mathrm{COOH} 1 \% / 6 \% \mathrm{NaOH}$ and $\% \mathrm{CH}_{3} \mathrm{COOH}$ & $2.7 \times 10^{4 \mathrm{a}}$ \\
Bakto agar OXOID/Bacto agar OXOID & $1.9 \times 10^{4 a}$ \\
\hline
\end{tabular}

Keterangan/Note: Huruf yang sama menunjukkan tidak berbeda nyata/The same letters indicate no significant difference. 
$\mathrm{CH}_{3} \mathrm{COOH} 0,5 \%$ yang telah memenuhi beberapa spesifikasi bakto agar komersial untuk parameter kadar air, kadar abu, kadar abu tak larut asam dan kekuatan gel. Karakteristik mutu dari praperlakuan tersebut adalah kadar air 13,69 $\pm 1,02 \%$, kadar abu $4,24 \pm 1,28 \%$, kadar abu tak larut asam $0,54 \pm 0,25 \%$, kadar sulfat $1,55 \pm 0,36 \%$, rendemen $9,19 \pm 2,21 \%$, kekuatan gel $1464,98 \pm 109,09 \mathrm{~g} / \mathrm{cm}^{2}$, viskositas $42,75 \pm 24,40 \%$, sineresis $2,76 \pm 0,12 \%$, titik jendal $20,50 \pm 2,12{ }^{\circ} \mathrm{C}$, dan titik leleh $95,25 \pm 1,06{ }^{\circ} \mathrm{C}$. Praperlakuan dengan konsentrasi tersebut juga memiliki nilai ALT yang sama dengan bakto agar komersial.

\section{DAFTAR PUSTAKA}

Abidin, Z., Marcellino, R., \& Sudjarwo. (2015). Isolasi dan karakterisasi agarosa dari rumput laut Gracilaria verrucosa. Jurnal IImu Kefarmasian Indonesia, 13, 69-75.

Al-Nahdi, Z. M., Al-Alawi, A., Al-Marhobi, I, \& Al-Zefiti, A. (2015). Optimization of yield and chemical properties of agar extracted from Melanothamnus somalensis from Oman Sea. Journal of Environmental Science and Engineering, 4, 302-314.

Anonymous. (2004). Supreme Marine Chemical. Http:// geocities.com/agar-agar/Supreme.html.

Armisen, R. \& Galatas, F. 2009. Agar. In: Handbook of Hydrocolloids, Williams, P.A. And Phillips, G.O. (eds.). Woodhead Publishing. Cambridge, U.K.

Arvizu-Higuera, D. L., Rodríguez-Montesinos, Y. E., Murillo-Álvarez, J. I. , Muñoz-Ochoa, M., \& HernándezCarmona, G. (2008) Effect of alkali treatment time and extraction time on agar from Gracilaria vermiculophylla. J. Appl. Phycol., 20, 515-519.

Badan Standardisasi Nasional (BSN). (2006a). Cara Uji Mikrobiologi. SNI 01-2332.1-2006. Jakarta (ID) : BSN.

Badan Standarisasi Nasional (BSN). (2006b). Cara uji kimia-Bagian 2: Penentuan kadar air pada produk perikanan. SNI 01-2354.2-2006. Jakarta (ID). BSN.

Badan Standarisasi Nasional (BSN). (2006c). Cara uji kimia-Bagian 1: Penentuan kadar abu pada produk perikanan. SNI 01-2354.1-2006. Jakarta (ID). BSN.

Badan Standardisasi Nasional (BSN). (2010). Penentuan Kadar Abu dan Abu Tak Larut Asam pada Produk Perikanan. SNI 2345.1:2010. Jakarta (ID) : BSN.

Badan Standardisasi Nasional (BSN). (2015a). Penentuan Clean Anhydrous Weed (CAW) pada Rumput Laut Kering. SNI 8168:2015. Jakarta (ID) : BSN.

Badan Standardisasi Nasional (BSN). (2015b). Penentuan impurities pada Rumput Laut. SNI 8169:2015. Jakarta (ID) : BSN.

Badan Standardisasi Nasional (BSN). (2015c). Penentuan Kadar Air pada Produk Perikanan. SNI 2345.2:2015. Jakarta (ID) : BSN.

Badan Standardisasi Nasional (BSN). (2015d). Rumput Laut Kering. SNI 2690:2015. Jakarta (ID) : BSN.

Sousa, A. M. M., Alves, V. D., Morais, S., Matos, C. D., \& Gonçalves, M. P. (2010). Agar extraction from integrated multitrophic aquacultured Gracilaria vermiculophylla: Evaluation of a microwave-assisted process using response surface methodology. Bioresource Technology, 101, 3258-3267.

Chirapart, A., Munkit, J., \& Lewmanomont, K. (2006). Changes in yield and quality of agar from the agarophytes, Gracilaria fisheri and G. tenuistipitata var. liui cultivated in Earthen Ponds. Kasetsart Journal (Natural Science), 40, 529-540.

Czechowska-Biskup, R., Jarosinska, D., Rokita, B., Ulanski, P., \& Rosiak, J. M. (2012). Determination of degree of deacetylation of chitosan-comparision of methods. Progress on Chemistry and Appication of Citin, 16, 5-20.

Darmawan, M., Syamdidi, \& Hastarini, E. (2006). Pengolahan bakto agar dari rumput laut merah (Rhodymenia ciliata) dengan praperlakuan alkali. Jurnal Pascapanen dan Bioteknologi Kelautan dan Perikanan, 1(1), 9-18.

Distantina, S., Rusman, O., \& Hartati, S. (2006). Pengaruh konsentrasi $\mathrm{CH}_{3} \mathrm{COOH}$ pada perendaman terhadap kecepatan ekstraksi agar-agar. Ekuilibrium, 5(1), 34-39.

Distantina, S., Anggraeni, D. R., \& Fitri, L.E. (2008). Pengaruh konsentrasi dan jenis larutan perendaman terhadap kecepatan ekstraksi dan sifat gel agar-agar dari rumput laut Gracilaria verrucosa. Jurnal Rekayasa Proses, 2(1), 11-16.

Efendi, F., Retno, H., \& Nursalam. (2015). Searching for the best agarose candidate from genus Gracilaria, Eucheuma, Gelidium and local brands. Asian Pacific Journal of Tropical Biomedicine, 5(10), 865-869.

Fleire-Pelegrin, Y., \& Murano, E. (2005). Agars from three species of Gracilaria (Rhodophyta) from Yucatan Peninsula. Bioresource Technology, 96, 295-302.

Ganesan, M., \& Rao, P.V.S. (2004). Influence of postharvest treatment onshelf life and agar quality in seaweeds Glacilaria edulis (Rhodophyta/ Gigartinales) and Gelidiella acerosa (Rhodophyta/ Gelidiales). Indian Journal and Marina Sciences 33(3), 269-275.

Gómez-Ordóñez, E., \& Rupérez, P. (2011). FTIR-ATR spectroscopy as a tool for polysaccharide identification in edible brown and red seaweeds. Food Hydrocolloids, 25, 1514-1520.

Guerrero, P., Etxabide, A., Leceta, I., Pernalba, M., \& de La Caba, K. (2014). Extraction of agar from Gelidium sesquipedale (Rodhopyta) and surface characterization of agar based films. Carbohydrate Polymers, 99, 491- 498.

Heydari, M., Nematollahi, M. A., Motamedzadegan, A., Hosseini-Parvar, S. H., \& Hosseini, S. H. (2014). Optimization of the yield and quality of agar from Gracilariopsis persica. Bulletin of Environmental Pharmacology Life Science, 3 (3), 33-40

Humm, T. J., \& Williams, L. G. (1948). A study of agar from two Brazilian seaweed. American Journal of Botany, 35(5), 287-292.

Knudsen, N. R., Marcel, T. A., \& Anne, S. M. (2015). Seaweed hydrocolloid production: an update on enzyme assisted extraction and modification technologies. Marine Drugs, 13, 3340-3359. 
Pengaruh Praperlakuan Alkali dan Asam terhadap Karakteristik Mutu Bakto Agar ....(Muhamad Darmawan et al.,)

Kumala, S., Sumarny, R., Racmani, R., \& Ruswita, A. (2013). Alga merah (Gracilaria verrucosa) sebagai bahan bakto agar. Jurnal Farmasi Indonesia, 6(3), 167-171.

Kusuma, W. I., Santosa, G. W., \& Pramesti, R. (2013). Pengaruh konsentrasi $\mathrm{NaOH}$ yang berbeda terhadap mutu agar dari rumput laut Gracilaria verrucosa. Journal of Marine Research, 2(2), 120-129.

Lee, W., Namasivayam, P., \& Ho, C. (2014). Effects of sulfate starvation on agar polysaccharides of Gracilaria species (Gracilariaceae, Rhodophyta) from Morib, Malaysia. Journal of Applied Phycology, 26, 1791-1799.

McHugh, D.J. (2003). A Guide to The Seaweed Industry. Roma (IT) : FAO Fisheries Technical Paper 441. Hal 18.

Meena, R., Prasad, K., Ganesan, M., \& Siddhanta, A. K. (2008). Superior quality agar from Glacilaria spesies (Gracilariales, Rhodophyta) collected from the Gulf of Mannar, India. Journal of Applied Phycology, 20, 397-402.

Murdinah, Fransiska, D., \& Subaryono. (2008). Pembuatan bakto agar dari rumput laut Gelidium rigidum untuk media tumbuh bagi mikroorganisme. Jurnal Pascapanen dan Bioteknologi Kelautan dan Perikanan, 1(1), 79-88.

Murdinah, Apriani, S. N. K., Nurhayati, \& Subaryono. (2012). Membuat Agar dari Rumput Laut Glacilaria sp. Jakarta (ID), Penebar Swadaya.pp 23.

Nil, S., Ali-Mehidi, S., Zellal, A., Abi-Ayad, S.M. (2016). Effects of season on the yield and quality of agar from Gelidium sesquipedale (Rhodophyta) from Mostaganem, Algeria. African Journal of Technology, 15(10), 350-355.

Niu, J., Xu, M., Wang, G., Zhang, K., \& Peng, G. (2013). Comprehensive extraction of agar r-phycoerythrin from Gracilaria lemaneiformis (Bangiales, Rhodophyta). Indian Journal of Geo-Marine Science, 42(1), 21-28.

Orduña-Rojas, J., Suárez-Castro, R., López-Álvarez, E. S., Ríosmena-Rodríguez, R., I Pacheco-Ruiz, Zertuche-González, R., \& Meling-López, A. E. (2008). Influence of alkali treatment on agar from Gracilariopsis Iongissima and Gracilaria vermiculophylla from the Gulf of California, Mexico. Ciencias Marinas, 34(4), 503-511.

Praiboon, J., Chirapart, A., Akakabe, Y., Bhumibhamon, O., \& Kajiwara, T. (2006). Physical and chemical characterization of agar polysaccharides extracted from the Thai and Japanese species of Gracilaria. Science Asia, 32(1), 11-17.

Ramalingam, J.R., Kaliaperumal, N., \& Kalimuthu, S. (2002). Agar production from Glacilaria with improved qualities. Seaweed Research and Utilization, 24(1), 25-34.

Rodríguez-Montesinos, Y. E., Arvizu-Higuera, D. L., Hernández-Carmona, G., Muñoz-Ochoa, M., \& MurilloÁlvarez, J. I. (2013). Seasonal variation of the agar quality and chemical composition of Gracilaria veleroae and Gracilaria vermiculophylla (Rhodophyceae, Gracilariaceae) from Baja California Sur, Mexico. Phycological Research, 61,116-123.

Sahu, N., \& Sahoo, D. (2013). Study of morphology and agar contents in some important Gracilaria species of Indian Coasts. American Journal of Plant Sciences,4, 52-59.

Salamah, E., Susanti, D., \& Wikanta, T. (2005). Kualitas agarosa hasil isolasi dari Rhodymenia ciliata menggunakan deae-selulosa. Buletin Teknologi Hasil Perikanan, 5(1), 13-20.

Santika, L. G., Widodo, F. M., \& Romadhon. (2014). Karakteristik agar rumput laut Gracilaria verrucosa budidaya tambak dengan perlakuan konsentrasi alkali pada umur panen yang berbeda. Jurnal Pengolahan dan Bioteknologi Hasil Perikanan, 2(4), 98-105.

Siddique, M.A.M., Khan, M. S. K., \& Buiyan, M. K. A. (2013). Nutritional composition and amino acid profile of a subtropical red seaweed Gelidium pusillum collected from St. Martin's Island, Bangladesh. International Food Research Journal, 20(5), 2287-2292.

Subaryono, \& Murdinah. (2011). Kualitas agar-agar dari rumput laut Gracilaria chilensis yang dibudidayakan di Lampung [prosiding]. Forum Inovasi Teknologi Akuakultur, 1153-1158.

Utomo, B. S. B., \& Satriyana, N. (2006). Sifat fisiko-kimia agar-agar dari rumput laut Gracilaria chilensis yang diekstrak dengan jumlah air berbeda. Jurnal IImu-IImu Perairan dan Perikanan Indonesia, 13(1), 45-50.

Villanueva, R. D., Sousa, A. M. M., Gonçalves, M. P., Nilsson, M., \& Hilliou, L. (2010). Production and properties of agar from the invasive marine alga, Gracilaria vermiculophylla (Gracilariales, Rhodophyta). Journal of Applied Phycology, 22, 211-220.

Wenno, M. R., Thenu, J. L., \& Lopulalan, C. G. C. (2012). Karakteristik kappa karaginan dari Kappaphycus alvarezii pada berbagai umur panen. Jurnal Pascapanen dan Bioteknologi Perikanan, 7(1), 61-67.

Yarnpakdee, S., Soottawat, B., \& Passakorn, K. (2015). Physico-chemical and gel properties of agar from Gracilaria tenuistipitata from the lake of Songkhla, Thailand. Food Hydrocolloids, 51, 217-226.

Yousefi, M. K., Islami, H. R., \& Filizadeh, Y. 2013. Effect of extraction process on agar properties of Gracilaria corticata (Rhodophyta) collected from the Persian Gulf. Phycologia, 52(5), 1-7. 